\title{
Hydrological management for improving nutrient assimilative capacity in plant-dominated wetlands: a modelling approach
}

Zhihao $\mathrm{Xu}^{\mathrm{a}}$, Zhifeng Yang ${ }^{\mathrm{a}, *}$, Xinan Yin ${ }^{\mathrm{a}, *}$, Yanpeng Cai ${ }^{\mathrm{a}}$, Tao Sun ${ }^{\mathrm{a}}$

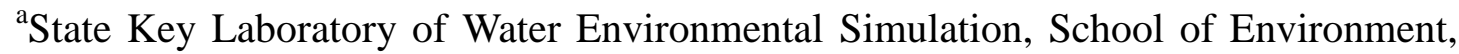

Beijing Normal University, No. 19, Xinjiekouwai Street, Haidian District, Beijing, China, 100875.

${ }^{*}$ Corresponding author:

Zhifeng Yang (E-mail: zfyang@bnu.edu.cn; Tel./fax: +86 10 5880-7596)

and Xinan Yin (E-mail: yinxinan@ bnu.edu.cn; Tel./fax: +86 10 5880-4037)

Post address: School of Environment, Beijing Normal University, No. 19,

Xinjiekouwai Street, Haidian District, Beijing, China, 100875.

E-mail address of other authors:

Zhihao Xu: zhihaoxu@mail.bnu.edu.cn;

Yanpeng Cai: yanpeng.cai@bnu.edu.cn;

Tao Sun: suntao@bnu.edu.cn 
Abstract: Wetland eutrophication is a global environmental problem. Besides reducing pollutant emissions, improving nutrient assimilative capacity in wetlands is also significant for preventing eutrophication. Hydrological management can improve nutrient assimilative capacity in wetlands through physical effects on the dilution capacity of water body and ecological effects on wetland nutrient cycles. The ecological effects are significant while were rarely considered in previous research. This study focused on the ecological effects of hydrological management on two crucial nutrient removal processes, plant uptake and biological denitrification, in plant-dominated wetlands. A dual-objective optimization model for hydrological management was developed to improve wetland nitrogen and phosphorus assimilative capacities, using upstream reservoir release as water regulating measure. The model considered the interactions between ecological processes and hydrological cycles in wetlands, and their joint effects on nutrient assimilative capacity. Baiyangdian Wetland, the largest freshwater wetland in northern China, was chosen as a case study. The results found that the annual total assimilative capacity of nitrogen (phosphorus) was 4754 (493) $t$ under the optimal scheme for upstream reservoir operation. The capacity of nutrient removal during the summer season accounted for over $80 \%$ of the annual total removal capacity. It was interesting to find that the relationship between water inflow and nutrient assimilative capacity in a plant-dominated wetland satisfied a dose-response relationship commonly describing the response of an organism to an external stressor in the medical field. It illustrates that a plant-dominated wetland shows similar characteristics to an organism. This study offers a useful tool and some 
fresh implications for future management of wetland eutrophication prevention.

Keywords: eutrophication; nitrogen; phosphorus; hydrology; management model

\section{Introduction}

Nutrient assimilative capacity is defined as the maximum allowable nutrient load that can be received by a water body without significant damage to water consumers and ecosystem health (Landis, 2008). It is commonly used for directing pollutant emission control in the Total Maximum Daily Load (TMDL) program (Faulkner, 2008; Hall et al., 2014). With the rapid increase of water consumption, nutrient assimilative capacity in many wetlands has been damaged (Haddeland et al., 2014; Rost et al., 2008), while external nutrient discharge has greatly increased and brought intense pressure on water environments (Shantz and Burkepile, 2014; Zhang et al., 2015). Improving nutrient assimilative capacity is significant and necessary for protecting water resources and aquatic ecosystems in worldwide wetlands.

Hydrological management can improve nutrient assimilative capacity in wetlands (Mangangka et al., 2015; Sha et al., 2013). Water release from upstream reservoirs is a common measure for wetland hydrological management. Many studies on reservoir operation have focused on water release for improving downstream water quality (e.g.,

Belayneh and Bhallamudi, 2012; Kunz et al., 2013; Yoon et al., 2014). Several models for simulating downstream water quality were linked to reservoir operation optimization models (Dhar and Datta, 2008; Soltani et al., 2010). Water quality protection is now an important target in water quantity allocation (Castelletti et al., 
2013; Ferreira and Teegavarapu, 2012). New multi-objective optimization approaches were developed as a result of multiple reservoir operation targets (Adeyemo, 2011; Kurek and Ostfeld, 2013; Reddy and Kumar, 2007). Some creative operating approaches and rules were proposed for decision makers to resolve the interest conflicts of multiple stakeholders (Kerachian and Karamouz, 2006; Teegavarapu et al., 2013). These studies provided useful tools for directing reservoir operation and planning for downstream water quality protection.

Upstream reservoir release can improve the nutrient assimilative capacity in downstream wetlands by improving the nutrient dilution capacity of water bodies, while it also affects nutrient assimilative capacity through ecological effects on wetland nutrient removal processes, which rarely has been considered. This study focuses on the ecological effects of hydrological regulation in a plant-dominated wetland, which is a common and important wetland type with high species richness and service value (Jones and Waldron, 2003). Plant uptake and biological denitrification are two crucial nutrient removal processes in plant-dominated wetlands (Havens and Schelske, 2001; Marion and Paillisson, 2003). They play important roles in determining nutrient assimilative capacity of these wetlands, due to their prominent contributions to nutrient removal (Borges et al., 2016; Gottschall et al., 2007).

Hydrological condition is an important wetland characteristic affecting plant uptake and biological denitrification. Most plants only grow in specific, suitable water-depth conditions (Bucak et al., 2012; Pagter et al., 2005), so hydrological conditions largely determine plant area in a wetland. Within suitable growing zones, 
the biomass and nutrient accumulative capacity of plants differ significantly in seasonally flooded and continuously flooded conditions (Ahn and Dee, 2011; Sollie and Verhoeven, 2008). Besides plant uptake, biological denitrification is also affected by hydrological regulation through the effects on nitrogen availability, soil moisture, and redox conditions (Berglund and Berglund, 2011; Song et al., 2010). Biological denitrification in seasonally flooded conditions is stronger than that in continuously flooded conditions (Yang et al., 2012). These works demonstrated the effects of hydrological differences on plant uptake and biological denitrification, but existing reservoir operation research rarely has considered ecological effects of water release on the two processes. Without considering these, upstream water release may damage plant uptake and biological denitrification, resulting in negative effects on nutrient assimilative capacity in downstream wetlands. A reservoir operation approach simultaneously considering the dilution effects and ecological effects of water release is needed urgently for rational use of upstream water resources and protection of downstream water quality.

In this study, a reservoir operation optimization model is proposed for maximizing nutrient assimilative capacity in the downstream plant-dominated wetland under limited water resource availability. This model simultaneously considers the improvement of dilution capacity caused by increased water and the ecological effects of hydrological changes on nutrient cycles in wetlands. We divided the entire wetland area into several hydrological zones and determined the differences of plant uptake and biological denitrification in various zones though experiments. Nitrogen $(\mathrm{N})$ and 
phosphorus (P), two significant nutrient pollutants in global freshwater wetlands (Bernhardt, 2013; Conley et al., 2009), are both considered in the model. We applied a genetic algorithm to solve the model and suggest an optimal operation scheme for upstream reservoirs. Last, based on the optimization model, we attempt to find the relationship between upstream water release and nutrient assimilative capacity in the downstream plant-dominated wetland, and offer some implications for future water resources management and protection.

\section{Material and methods}

\subsection{Study area}

Baiyangdian Wetland (Figure 1) is a famous and typical plant-dominated wetland located in Hebei Province, China. The maximum water surface area is $308 \mathrm{~km}^{2}$ when the wetland's water level reaches $8.8 \mathrm{~m}$, and the minimum area is $46 \mathrm{~km}^{2}$ when the water level decreases to $6 \mathrm{~m}$. The common reed (Phragmites australis (Cav.) Trin. ex Steud.) is the dominant plant species and covers approximately $80 \mathrm{~km}^{2}$. The reed growing season is from April to September. Harvested reeds remove large amounts of nutrients from the wetland and bring significant economic benefits to the local residents. However, in recent years, the services and functions provided by Baiyangdian Wetland have been damaged due to water quality deterioration resulting from excessive $\mathrm{N}$ and $\mathrm{P}$ input. Water consumption by upstream reservoirs decreases inflows to the wetland and reduces wetland nutrient assimilative capacity. Now, water release to increase nutrient assimilative capacity in Baiyangdian Wetland has become 
an important target for upstream reservoir operation.

\#The approximate position of Figure 1\#

\subsection{Optimization model development and application}

A dual-objective reservoir operation optimization model aimed at improving both $\mathrm{N}$ and $\mathrm{P}$ assimilative capacities in wetlands is developed and applied in Baiyangdian Wetland as a case study. The model framework is shown in Figure 2.

\#The approximate position of Figure 2\#

\subsubsection{Wetland water balance}

Water volume is an important factor affecting nutrient assimilative capacity in wetlands. Monthly variations of wetland water volume can be obtained based on water balance. In general, wetland water replenishment depends on local precipitation and inflows from upstream regions, and water losses occur through outflows, deep drainage, and evapotranspiration (Ranieri, 2003). Evapotranspiration calculation for plant-dominated wetlands is a complex process. In the plant growing season, both water surface evaporation and plant community transpiration need to be considered. Plant area is affected by hydrological conditions, so plant area variations caused by hydrological changes are considered in calculating wetland evapotranspiration. The evapotranspiration capacity of zones with reeds or without reeds in Baiyangdian Wetland is determined based on the research by $\mathrm{Xu}$ et al. (2014). The wetland now has little outflow, which can be ignored. The rate of deep drainage water loss is $3 \mathrm{~mm}$ per day and average annual precipitation in the wetland area is $461.9 \mathrm{~mm}$ (Xu et al., 2014). Inflows from upstream regions are controlled by upstream reservoirs, which 
will be optimized in this study. The equation to calculate monthly wetland water volume is:

$W_{i}=W_{i-1}+W_{\mathrm{in}, i}+W_{\mathrm{r}, i}-W_{\mathrm{o}, i}-W_{\mathrm{e}, i}-W_{\mathrm{d}, i}$

where $W_{i}$ is the wetland water volume in month $i(1-12)\left(\times 10^{8} \mathrm{~m}^{3}\right) ; W_{\mathrm{in}, i}$ is the water replenishment through inflows $\left(\times 10^{8} \mathrm{~m}^{3}\right) ; W_{\mathrm{r}, i}$ is the water replenishment through rainfall $\left(\times 10^{8} \mathrm{~m}^{3}\right) ; W_{\mathrm{o}, i}$ is the water loss through outflows $\left(\times 10^{8} \mathrm{~m}^{3}\right) ; W_{\mathrm{e}, i}$ is the water loss through evapotranspiration $\left(\times 10^{8} \mathrm{~m}^{3}\right)$; and $W_{\mathrm{d}, i}$ is the water loss through deep drainage $\left(\times 10^{8} \mathrm{~m}^{3}\right)$.

\subsubsection{Nutrient mass balances}

Natural wetlands have strong capacity to remove nutrients from wetland water. Generally, both nitrogen and phosphorus can be removed from water bodies through outflows, plant uptake, and exchange with sediments, while nitrogen can also be removed through ammonia volatilization, chemical denitrification, and biological denitrification (Zhao et al., 2012). Chemical denitrification usually occurs in acidic environments and ammonia volatilization is not significant in environments with $\mathrm{pH}$ values ranging from 7.5 to 9.3 (Zhao et al., 2012). Baiyangdian Wetland is weakly alkaline with $\mathrm{pH}$ value of approximately 8.0 (Xu et al., 2014), so nitrogen removal through chemical denitrification and ammonia volatilization is negligible. The equations to calculate the monthly amounts of $\mathrm{N}$ and $\mathrm{P}$ in a wetland water body are:

$N_{i}=N_{i-1}+N_{\mathrm{in}, i}-N_{\mathrm{o}, i}-N_{\mathrm{e}, i}-N_{\mathrm{p}, i}-N_{\mathrm{a}, i}-N_{\mathrm{c}, i}-N_{\mathrm{b}, i}$

$P_{i}=P_{i-1}+P_{\mathrm{in}, i}-P_{\mathrm{o}, i}-P_{\mathrm{e}, i}-P_{\mathrm{p}, i}$

where $N_{i}$ and $P_{i}$ are the amounts of $\mathrm{N}$ and $\mathrm{P}$ in the wetland water in month $i\left(\times 10^{2} \mathrm{t}\right)$; 
$N_{\mathrm{in}, i}$ and $P_{\mathrm{in}, i}$ are the amounts of $\mathrm{N}$ and $\mathrm{P}$ going into the wetland water $\left(\times 10^{2} \mathrm{t}\right) ; N_{\mathrm{o}, i}$ and $P_{\mathrm{o}, i}$ are the amounts removed by outflows $\left(\times 10^{2} \mathrm{t}\right) ; N_{\mathrm{e}, i}$ and $P_{\mathrm{e}, i}$ are the amounts removed by exchange with sediments $\left(\times 10^{2} \mathrm{t}\right) ; N_{\mathrm{p}, i}$ and $P_{\mathrm{p}, i}$ are the amounts removed by plant uptake $\left(\times 10^{2} \mathrm{t}\right) ; N_{\mathrm{a}, i}$ is the amount of $\mathrm{N}$ removed by ammonia volatilization $\left(\times 10^{2} \mathrm{t}\right) ; N_{\mathrm{c}, i}$ is the amount of $\mathrm{N}$ removed by chemical denitrification $\left(\times 10^{2} \mathrm{t}\right)$; and $N_{\mathrm{b}, i}$ is the amount of $\mathrm{N}$ removed by biological denitrification $\left(\times 10^{2} \mathrm{t}\right)$.

\subsubsection{Ecological effects of hydrological regulation}

The nutrient removal capacities of plant uptake and biological denitrification are different for the continually submerged and intermittently submerged zones. In addition, in the same hydrological zone, the intensity of biological denitrification is different for zones with plants and without plants, because plant rhizosphere environments facilitate biological denitrification by improving the exchange of aerobic and anaerobic processes in sediments. Based on differences of plant uptake and biological denitrification, we divide the submerged wetland area into four zones: a continually submerged zone with plants $\left(A_{1, \mathrm{p}}\right)$; a continually submerged zone without plants $\left(A_{1, \mathrm{np}}\right)$; an intermittently submerged zone with plants $\left(A_{2, \mathrm{p}}\right)$; and an intermittently submerged zone without plants $\left(A_{2, \text { np }}\right)$. The equations to calculate the amounts of $\mathrm{N}$ and $\mathrm{P}$ removed by plant uptake and biological denitrification are:

$$
\begin{aligned}
& A_{i}=A_{1, \mathrm{p}, i}+A_{1, \mathrm{np}, i}+A_{2, \mathrm{p}, i}+A_{2, \mathrm{np}, i} \\
& N_{\mathrm{p}, i}=n_{1, \mathrm{p}, i} \times A_{1, \mathrm{p}, i}+n_{2, \mathrm{p}, i} \times A_{2, \mathrm{p}, i} \\
& P_{\mathrm{p}, i}=p_{1, \mathrm{p}, i} \times A_{1, \mathrm{p}, i}+p_{2, \mathrm{p}, i} \times A_{2, \mathrm{p}, i} \\
& N_{\mathrm{b}, i}=n_{\mathrm{b}, 1 \mathrm{p}, i} \times A_{1, \mathrm{p}, i}+n_{\mathrm{b}, 1 \mathrm{np}, i} \times A_{1, \mathrm{np}, i}+n_{\mathrm{b}, 2 \mathrm{p}, i} \times A_{2, \mathrm{p}, i}+n_{\mathrm{b}, 2 \mathrm{np}, i} \times A_{2, \mathrm{np}, i}
\end{aligned}
$$


where $A_{i}$ is the total submerged wetland area in month $i\left(\mathrm{~km}^{2}\right) ; n_{1, \mathrm{p}, i}$ and $p_{1, \mathrm{p}, i}$ are the amounts of $\mathrm{N}$ and $\mathrm{P}$ absorbed by plants in a unit of the continually submerged area $\left(\times 10^{2} \mathrm{t} \mathrm{km}^{-2}\right) ; n_{2, \mathrm{p}, i}$ and $p_{2, \mathrm{p}, i}$ are the amounts absorbed by plants in a unit of the intermittently submerged area $\left(\times 10^{2} \mathrm{t} \mathrm{km}^{-2}\right) ; n_{\mathrm{b}, 1 \mathrm{p}, i}\left(n_{\mathrm{b}, 1 \mathrm{np}, i}\right)$ is the amount of $\mathrm{N}$ removed by biological denitrification in a unit of the continually submerged area with (without) plants $\left(\times 10^{2} \mathrm{t} \mathrm{km}^{-2}\right)$; and $n_{\mathrm{b}, 2 \mathrm{p}, i}\left(n_{\mathrm{b}, 2 \mathrm{np}, i}\right)$ is the amount of $\mathrm{N}$ removed by biological denitrification in a unit of the intermittently submerged area with (without) plants $\left(\times 10^{2} \mathrm{t} \mathrm{km}^{-2}\right)$.

Plant uptake and biological denitrification are two crucial nutrient removal processes in plant-dominated wetlands. Hydrological regulation affects both these two processes. On the one hand, hydrological regulation leads to wetland water-depth variations. Plants normally grow in suitable water depths, which range from -0.64 to $1.01 \mathrm{~m}$ for the common reed in Baiyangdian Wetland (Xu et al., 2014). In this model, the plant area is calculated based on the initial plant area and the wetland water-depth condition during the modelling period. As water depth varies, plant area may also have variations accordingly. When water depths in the plant growing zones become unsuitable for plant growth, these plants will die and be harvested to prevent the release of nutrients in the wetland. On the other hand, hydrological regulation also results in water surface area variation and affects wetland submerged condition. As previously mentioned, wetland submerged condition affects plant growth and the intensity of biological denitrification, which can be determined by experiments. 
In the case of Baiyangdian Wetland, the effects of hydrological difference on plant growth and biological denitrification are determined based on our experimental results (Zhao et al., 2013; Yang et al., 2012). We conducted field sampling and simulation experiments in 2010 to determine nutrient removal capacities of reed uptake and biological denitrification in different zones of Baiyangdian Wetland. The reed mass and nutrients absorbed by reed tissues in each month of the growing season were determined for the continually submerged and intermittently submerged zones (Table 1). The mass of reeds in the intermittently submerged zone is $2647.1 \mathrm{~g} \mathrm{~m}^{-2}$ at the end of the growing season and is $45 \%$ higher than that in the continually submerged zone. Although the nutrient concentrations of reeds in continually submerged zone are a little higher, reeds in intermittently submerged zone have stronger nutrient uptake capacity due to their higher biomass. The effects of hydrological difference on plant mass and nutrient uptake capacity are significant, which should be carefully considered in wetland hydrological management. Biological denitrification and exchange with sediments removed an average of 57.6 $\mathrm{mg} \mathrm{m}^{-2} \mathrm{~N}$ monthly from the water in the continually submerged zone without reeds, and removed an average of $67.9 \mathrm{mg} \mathrm{m}^{-2} \mathrm{~N}$ in the intermittently submerged zone without reeds. The $\mathrm{N}$ removed by biological denitrification in the zone with reeds was two times as great as that removed in the same hydrological zone without reeds. An average of $6.5 \mathrm{mg} \mathrm{m}^{-2} \mathrm{P}$ was removed from the water monthly through exchange with sediments in the wetland.

\#The approximate position of Table 1\# 


\subsubsection{Optimization objectives and constraints}

The objective of the optimization model is to maximize nutrient assimilative capacity in downstream plant-dominated wetlands under acceptable reservoir release plans. $\mathrm{N}$ and $\mathrm{P}$ assimilative capacities are the dual objectives of the model. Acceptable amounts of $\mathrm{N}$ and $\mathrm{P}$ have significant differences in the same wetland, so we set weighting coefficients for these two nutrients in building the optimization objective, which is shown as:

$f=\max \left(\lambda_{1} \sum_{i=1}^{12} M_{\mathrm{N}, i}+\lambda_{2} \sum_{i=1}^{12} M_{\mathrm{P}, i}\right)$

where $M_{\mathrm{N}, i}$ and $M_{\mathrm{P}, i}$ are the $\mathrm{N}$ and $\mathrm{P}$ assimilative capacities in month $i\left(\times 10^{2} \mathrm{t}\right)$; and $\lambda_{1}$ and $\lambda_{2}$ are the weighting coefficients. According to the local government, Baiyangdian Wetland is expected to meet the Chinese water quality standard Grade III, which requires that the $\mathrm{N}$ and $\mathrm{P}$ concentrations should be no higher than 1.0 and $0.05 \mathrm{mg} \mathrm{L}^{-1}$, respectively (SEPAC, 2002). The water quality standard shows that the acceptable amount of nitrogen is twenty times as high as that of phosphorus for the same wetland, so we set $\lambda_{1}$ and $\lambda_{2}$ as 0.05 and 1.0 in this case.

The model focuses on holistic mass balances in the wetland system and does not consider the spatial distribution of nutrients. The monthly nutrient amounts and water volume in a wetland can be obtained based on the mass balance calculations in section 2.2.1 and 2.2.2. The equations to assess $\mathrm{N}$ and $\mathrm{P}$ assimilative capacities are:

$$
\begin{aligned}
& C_{\mathrm{N}, i}=\frac{N_{i}}{W_{i}}=\frac{N_{i-1}+N_{\mathrm{in}, i}-N_{\mathrm{o}, i}-N_{\mathrm{e}, i}-N_{\mathrm{p}, i}-N_{\mathrm{a}, i}-N_{\mathrm{c}, i}-N_{\mathrm{b}, i}}{W_{i-1}+W_{\mathrm{in}, i}+W_{\mathrm{r}, i}-W_{\mathrm{o}, i}-W_{\mathrm{e}, i}-W_{\mathrm{d}, i}} \leq C_{\mathrm{N}, i}^{*} \\
& C_{\mathrm{P}, i}=\frac{P_{i}}{W_{i}}=\frac{P_{i-1}+P_{\mathrm{in}, i}-P_{\mathrm{o}, i}-P_{\mathrm{e}, i}-P_{\mathrm{p}, i}}{W_{i-1}+W_{\mathrm{in}, i}+W_{\mathrm{r}, i}-W_{\mathrm{o}, i}-W_{\mathrm{e}, i}-W_{\mathrm{d}, i}} \leq C_{\mathrm{p}, i}^{*}
\end{aligned}
$$


$M_{\mathrm{N}, i}=\max N_{\mathrm{in}, i}$

$M_{\mathrm{P}, i}=\max P_{\mathrm{in}, i}$

where $C_{\mathrm{N}, i}$ and $C_{\mathrm{P}, i}$ are the average $\mathrm{N}$ and $\mathrm{P}$ concentrations in wetland water in month $i$ $\left(\mathrm{mg} \mathrm{L}{ }^{-1}\right)$; and $C_{\mathrm{N}, i}{ }^{*}$ and $C_{\mathrm{P}}{ }^{*}, i$ are the maximum acceptable concentrations (mg L ${ }^{-1}$ ), which are 1.0 and $0.05 \mathrm{mg} \mathrm{L}^{-1}$ in the case of Baiyangdian Wetland.

In addition to the optimization objective, there are three constraints to be considered in the model, including:

(1) The available water volume released from upstream reservoirs for downstream wetlands is limited due to many other users of water resources. According to the current operation plans of upstream reservoirs, the maximum available water for Baiyangdian Wetland is $3.21 \times 10^{8} \mathrm{~m}^{3}$ annually. Future operation plans may change, so we will discuss the effects of parameter variations on the results in the discussion section. The constraint on the maximum available water is:

$\sum_{i=1}^{12} W_{\mathrm{in}, i} \leq W_{\max }$

where $W_{\max }$ is the maximum annual available water volume of upstream reservoirs for downstream wetlands $\left(\times 10^{8} \mathrm{~m}^{3}\right)$.

(2) Ecological water requirements need to be considered. To protect biological habitats and maintain wetland biodiversity, the water level in a wetland should be no lower than the basic ecological water level. The model set the basic level for Baiyangdian Wetland according to previous research (Yin and Yang, 2013). In addition, the magnitudes of water level fluctuations also affect wetland ecosystem health. The fluctuation between the highest and lowest monthly water levels through a 
year in Baiyangdian Wetland generally had magnitudes ranging from 0.5 to $2.5 \mathrm{~m}$ during the past decades (Yang et al., 2011). So the constraint on water level fluctuations in Baiyangdian Wetland is:

$0.5 \leq \max \left(L_{i}\right)-\min \left(L_{i}\right) \leq 2.5$

where $L_{i}$ is the wetland water level in month $i(\mathrm{~m})$.

(3) To avoid droughts and floods, the water level in Baiyangdian Wetland should be maintained constantly between 6 and $8.8 \mathrm{~m}$. The relationships among water level, water surface area, and water volume in Baiyangdian Wetland are obtained from historical data. The constraints on the characteristics of Baiyangdian Wetland are:

$6.0 \leq L_{i} \leq 8.8$

$W_{i}=0.37 L_{i}^{2}-4.03 L_{i}+10.83$

\subsection{Optimization model solution}

Genetic algorithms (GAs) are one stochastic method widely used for multi-objective optimization (Mitchell, 1998). These algorithms generate an initial population of random individuals and continually create subsequent generations by mimicking the processes of natural evolution (inheritance, mutation, and crossover). By evaluating the fitness of each individual, an optimal one is finally suggested as the solution of the optimization model. In recent years, GAs have been successfully used in numerous reservoir operation and water resource management studies (e.g., Bai et al., 2015; Teegavarapu et al., 2013; Yin and Yang, 2013). Therefore, a GA is chosen as the optimization model solution method in this study. 


\section{Results and discussion}

\subsection{Optimal operation scheme for upstream reservoirs}

An optimal operation scheme (Figure 3) considering both dilution effects and ecological effects of water release is suggested for upstream reservoirs by applying the model in Baiyangdian Wetland. The annual total volume of water released is $3.21 \times 10^{8} \mathrm{~m}^{3}$. Under this scheme, the water level in the wetland fluctuates between 7.2 and $8 \mathrm{~m}$ throughout the year, which meets the ecological water requirements of the wetland. Reeds remove significant amounts of nutrients from the wetland, but they also take large quantities of water away through evapotranspiration. In Baiyangdian Wetland, reeds have a large growing area of approximately $80 \mathrm{~km}^{2}$. The enormous water consumption by evapotranspiration leads to a significant decrease of wetland water volume. If little water flows into the wetland during the reed growing season, the water surface area and the area of submerged reeds will decrease. A decrease in submerged reed area leads to negative effects on nutrient assimilative capacity. Thus, the most water is released during the reed growing season from May to September to improve plant uptake.

\#The approximate position of Figure 3\#

\subsection{Optimized nutrient assimilative capacity in Baiyangdian Wetland}

Monthly nutrient assimilative and removal capacities in Baiyangdian Wetland under the optimal operation scheme for upstream reservoirs are shown in Figure 4. The annual total assimilative capacities of $\mathrm{N}$ and $\mathrm{P}$ are 4754 and $493 \mathrm{t}$, respectively. The maximum occurs in July for $\mathrm{N}$ and in August for P. Nutrient removal capacity is 
the primary factor determining nutrient assimilative capacity in wetlands. We divide a whole year into two periods, plant growing season (from May to September for the reeds in Baiyangdian Wetland) and non-growing season. During the reed non-growing season, an average of $7.48 \mathrm{t} \mathrm{N}$ and $0.83 \mathrm{t} \mathrm{P}$ is removed from the wetland water body monthly. Biological denitrification and exchange with sediments are the primary contributors to the $\mathrm{N}$ removal, and the latter is the primary contributor to the $\mathrm{P}$ removal. During the reed growing season, nutrient removal capacity in wetlands greatly increases, because reed growth absorbs large amounts of nutrients and significantly improves biological denitrification in the wetland system. The total capacity of nutrient removal during the summer season (from June to August) reaches $4196 \mathrm{t}$ for $\mathrm{N}$ and $416 \mathrm{t}$ for $\mathrm{P}$, accounting for $87 \%$ (for $\mathrm{N}$ ) and $84 \%$ (for $\mathrm{P}$ ) of the annual total removal capacity. It illustrates that plant growth plays a crucial role in improving nutrient assimilative capacity and plant mass deeply affects nutrient removal capacity in plant-dominated wetlands.

\section{\#The approximate position of Figure 4\#}

From Figure 4, it also can be found that nutrient assimilative capacity is a little lower than removal capacity in most months. This is because nutrient assimilative capacity in wetlands is affected not only by removal capacity, but also by wetland volume variations. Water volume increase (e.g., upstream reservoir release) is positive in improving assimilative capacity and water volume decrease (e.g., evapotranspiration) is negative. Due to upstream limited water availability, the water volume in Baiyangdian Wetland gradually decreases in most months, so monthly 
nutrient assimilative capacity is lower than removal capacity. Water volume varies between $1.0 \times 10^{8}$ and $2.2 \times 10^{8} \mathrm{~m}^{3}$ throughout the year and the monthly differences are not large. However, monthly nutrient assimilative capacities in the wetland are very different, especially between the plant growing and non-growing seasons. Thus, in addition to dilution capacity improvement, the ecological effects of upstream water release on downstream nutrient removal processes are also significant and must be considered in reservoir operation.

\subsection{The importance of a reservoir operation scheme}

To demonstrate the significance of considering the ecological effects of water release, here we discuss the effects of a reservoir operation scheme on wetland nutrient assimilative capacity when the total water release volume is fixed. An assumptive scenario is compared with the optimal scenario proposed in this study. In the assumptive scenario, water is released to the downstream wetland equally in all months of a year, and the annual total volume of water released is the same as in the optimal scenario, $3.21 \times 10^{8} \mathrm{~m}^{3}$. Monthly $\mathrm{N}$ and $\mathrm{P}$ assimilative capacities under the optimal and assumptive scenarios are compared for Baiyangdian Wetland (Figure 5).

\section{\#The approximate position of Figure 5\#}

As seen in Figure 5, the annual total $\mathrm{N}(\mathrm{P})$ assimilative capacity under the assumptive scenario is only $56 \%(58 \%)$ of that under the optimal scenario, demonstrating the importance of a reservoir operation scheme to downstream nutrient assimilative capacity. In the plant growing season (May to September), assimilative capacity under the optimal scenario is much better, especially in the middle and later 
periods. The significant difference can be explained by the enormous water consumption caused by evapotranspiration. Because the water released to the wetland during the reed growing season under the assumptive scenario is not sufficient, wetland evapotranspiration leads to significant decreases of both wetland water volume and submerged plant area. The decrease in submerged plant area is the main reason for decreased assimilative capacity in the wetland in the middle and later periods of the plant growing season.

\subsection{A dose-response relationship in the wetland}

The maximum available water volume of upstream reservoirs for downstream wetlands is an important parameter of the model. We created different scenarios by changing this parameter. Annual total nutrient assimilative capacities in Baiyangdian Wetland under different annual release volumes, ranging from $1 \times 10^{8}$ to $9 \times 10^{8} \mathrm{~m}^{3}$, are shown in Figure 6. These values range from 1970 to $5723 \mathrm{t}$ for $\mathrm{N}$ and from 209 to 591 $\mathrm{t}$ for $\mathrm{P}$. By adding trend lines, it was found that the relationship between upstream total release and nutrient assimilative capacity in downstream plant-dominated wetland satisfies an EC50 dose-response relationship.

\#The approximate position of Figure 6\#

The dose-response relationship describes the effects on an organism caused by differing levels of exposure to an external stressor in a certain time (Crump et al., 1976). It is commonly used in the medical field to indicate the effectiveness of drug treatments or toxicity of substances on organisms. However, this study finds that the response of a wetland to water inflow also satisfies a dose-response relationship, in 
which inflowing water acts as an external stressor and the wetland acts as an organism. This is an interesting phenomenon illustrating that a wetland shows similar characteristics to a living system. The EC50 model is a commonly used dose-response model (Motulsky and Christopoulos, 2004) defined here as:

$$
y=A_{1}+\left(A_{2}-A_{1}\right) /\left(1+10^{(a-x) * b}\right)
$$

where $y$ is annual total nutrient assimilative capacity $(\mathrm{t}) ; x$ is the total volume of upstream water release $\left(\times 10^{8} \mathrm{~m}^{3}\right)$; and $A_{1}, A_{2}, a$, and $b$ are model parameters.

\section{\#The approximate position of Table 2\#}

By analyzing the EC50 model for the relationship between reservoir release and nutrient assimilative capacity in Baiyangdian Wetland, the model parameters and goodness-of-fit are determined (Table 2) and the model curves are shown as the trend lines in Figure 6. According to the figure, nutrient assimilative capacity generally goes up as upstream water release increases, but improvement of assimilative capacity is insignificant when the total water release volume exceeds $5 \times 10^{8} \mathrm{~m}^{3}$. According to the modelling results, when the total release volume reaches $5 \times 10^{8} \mathrm{~m}^{3}$, the volume of water released during the plant growing season reaches a maximum of approximately $3.3 \times 10^{8} \mathrm{~m}^{3}$ and then does not continue to go up as the total release increases. This means that plant uptake performs best under an optimal hydrological condition, which is obtained when the total volume of water released during the plant growing season is $3.3 \times 10^{8} \mathrm{~m}^{3}$. Excessive or insufficient releases are both detrimental to plant uptake. When the total release exceeds $5 \times 10^{8} \mathrm{~m}^{3}$, the release volume during the plant growing season maintains a constant $\left(3.3 \times 10^{8} \mathrm{~m}^{3}\right)$, and the rest of the water is released outside 
the growing season. Increasing water release during the plant non-growing season is insignificant for improving annual total nutrient assimilative capacity. That is why the improvement in assimilative capacity was unremarkable when the total water release exceeded $5 \times 10^{8} \mathrm{~m}^{3}$. According to the EC50 dose-response relationship, we suggest that the optimal volume of annual total water release for Baiyangdian Wetland is $5 \times 10^{8} \mathrm{~m}^{3}$ and $66 \%$ should be released during the reed growing season.

\section{Conclusions}

Upstream reservoir release affects nutrient assimilative capacity in downstream plant-dominated wetlands through physical effects on dilution capacity and ecological effects on plant uptake and biological denitrification. A dual-objective optimization model considering these two effects was proposed for directing upstream reservoir operation, aiming at improving both $\mathrm{N}$ and $\mathrm{P}$ assimilative capacities in downstream wetlands. GA, a widely used optimization algorithm, was chosen to solve the model. By applying the model in Baiyangdian Wetland, an optimal reservoir operation scheme was suggested, under which the annual total nitrogen (phosphorus) assimilative capacity in the wetland is $79 \%(75 \%)$ higher than that when the same volume of water is released equally in all months of a year. The nutrient assimilative capacity during the plant growing season is significantly higher than that outside the growing season, demonstrating the importance of plant uptake in improving nutrient assimilative capacity of plant-dominated wetlands.

Upstream water release is helpful to improve downstream nutrient assimilative 
capacity, but the help offered by increasing water release is insignificant after the total release volume exceeds a certain value. The optimal volume of annual total water release for Baiyangdian Wetland was $5 \times 10^{8} \mathrm{~m}^{3}$ and $66 \%$ should be released during the plant growing season. Excessive or insufficient water releases during the plant growing season are both detrimental to plant nutrient uptake. It was found that the relationship between upstream water release and nutrient assimilative capacity in the downstream Baiyangdian Wetland satisfied an EC50 dose-response relationship. This is an interesting phenomenon illustrating that a plant-dominated wetland shows similar characteristics to an organism, which offers some fresh implications for future wetland water research. The hydrological management approach proposed in this study offered a useful reference for future eutrophication prevention in worldwide plant-dominated wetlands. 


\section{Acknowledgment}

This research was supported by the National Natural Science Foundation of China (No. 51439001), the National Science Foundation for Innovative Research Group (No. 51421065), and the Fundamental Research Funds for the Central Universities.

\section{References:}

Adeyemo, J.A., 2011. Reservoir operation using multi-objective evolutionary algorithms-a review. Asian J. Sci. Res. 4(1), 16-27.

Ahn, C., Dee, S., 2011. Early development of plant community in a created mitigation wetland as affected by introduced hydrologic design elements. Ecol. Eng. 37(9), 1324-1333.

Bai, T., Wu, L., Chang, J.X., Huang, Q., 2015. Multi-objective optimal operation model of cascade reservoirs and its application on water and sediment regulation. Water Resour. Manag. 29(8), 2751-2770.

Belayneh, M.Z., Bhallamudi, S.M., 2012. Optimization model for management of water quality in a tidal river using upstream releases. J. Water Resour. Prot. 4(3), $149-162$.

Berglund, Ö., Berglund, K., 2011. Influence of water table level and soil properties on emissions of greenhouse gases from cultivated peat soil. Soil Biol. Biochem. 43(5), 923-931.

Bernhardt, E.S., 2013. Cleaner lakes are dirtier lakes. Science 342(6155), 205-206.

Borges, A.C., Zaparoli, B.R., de Matos, A.T., Miranda, S.T., Moreira, A.R., Ranieri, E., 
2016. Potential for denitrification in sequencing batch constructed wetlands cultivated with T. latifolia and C. zizanioides. Desalin. Water Treat. 57(12), 5464-5472.

Bucak, T., Saraoğlu, E., Levi, E.E., Nihan Tavşanoğlu, Ü., Idil Çakiroğlu, A., Jeppesen, E., Beklioğlu, M., 2012. The influence of water level on macrophyte growth and trophic interactions in eutrophic Mediterranean shallow lakes: a mesocosm experiment with and without fish. Freshwater Biol. 57(8), 1631-1642.

Castelletti, A., Yajima, H., Giuliani, M., Soncini-Sessa, R., Weber, E., 2013. Planning the Optimal Operation of a Multioutlet Water Reservoir with Water Quality and Quantity Targets. J. Water Resour. Plann. Manage. 140(4), 496-510.

Conley, D.J., Paerl, H.W., Howarth, R.W., Boesch, D.F., Seitzinger, S.P., Havens, K.E., Lancelot, C., Likens, G.E., 2009. Controlling eutrophication: nitrogen and phosphorus. Science 323(5917), 1014-1015.

Crump, K.S., Hoel, D.G., Langley, C.H., Peto, R., 1976. Fundamental carcinogenic processes and their implications for low dose risk assessment. Cancer Res. 36, 2973-2979.

Dhar, A., Datta, B., 2008. Optimal operation of reservoirs for downstream water quality control using linked simulation optimization. Hydrol. Process. 22(6), 842-853.

Faulkner, B.R., 2008. Bayesian modeling of the assimilative capacity component of nutrient total maximum daily loads. Water Resour. Res. 44(8), W08415.

Ferreira, A.R., Teegavarapu, R.S., 2012. Optimal and adaptive operation of a 
hydropower system with unit commitment and water quality constraints. Water Resour. Manag. 26(3), 707-732.

Gottschall, N., Boutin, C., Crolla, A., Kinsley, C., Champagne, P., 2007. The role of plants in the removal of nutrients at a constructed wetland treating agricultural (dairy) wastewater, Ontario, Canada. Ecol. Eng. 29(2), 154-163.

Haddeland, I., Heinke, J., Biemans, H., Eisner, S., Florke, M., Hanasaki, N., Konzmann, M., Ludwig, F., Masaki, Y., Schewe, J., Stacke, T., Tessler, Z.D., Wada, Y., Wisser, D., 2014. Global water resources affected by human interventions and climate change. P. Natl. Acad. Sci. USA 111(9), 3251-3256.

Hall, R.K., Guiliano, D., Swanson, S., Philbin, M.J., Lin, J., Aron, J.L., Schafer, R.J., Heggem, D.T., 2014. An ecological function and services approach to total maximum daily load (TMDL) prioritization. Environ. Monit. Assess. 186(4), 2413-2433.

Havens, K.E., Schelske, C.L., 2001. The importance of considering biological processes when setting total maximum daily loads (TMDL) for phosphorus in shallow lakes and reservoirs. Environ. Pollut. 113(1), 1-9.

Jones, J.I., Waldron, S., 2003. Combined stable isotope and gut contents analysis of food webs in plant-dominated, shallow lakes. Freshwater Biol. 48(8), 1396-1407.

Kerachian, R., Karamouz, M., 2006. Optimal reservoir operation considering the water quality issues: A stochastic conflict resolution approach. Water Resour. Res. 42(12), W12401.

Kunz, M.J., Senn, D.B., Wehrli, B., Mwelwa, E.M., Wüest, A., 2013. Optimizing 
turbine withdrawal from a tropical reservoir for improved water quality in downstream wetlands. Water Resour. Res. 49(9), 5570-5584.

Kurek, W., Ostfeld, A., 2013. Multi-objective optimization of water quality, pumps operation, and storage sizing of water distribution systems. J. Environ. Manage. $115,189-197$.

Landis, W.G., 2008. Assimilative capacity, in: Jorgensen, S.E., Fath, B. (Eds.), Encyclopedia of ecology. Elsevier, Oxford, pp. 264-268.

Mangangka, I.R., Liu, A., Egodawatta, P., Goonetilleke, A., 2015. Performance characterisation of a stormwater treatment bioretention basin. J. Environ. Manage. 150, 173-178.

Marion, L., Paillisson, J.M., 2003. A mass balance assessment of the contribution of floating-leaved macrophytes in nutrient stocks in an eutrophic macrophyte-dominated lake. Aquat. Bot. 75(3), 249-260.

Mitchell, M., 1998. An introduction to genetic algorithms. MIT Press, Cambridge, MA.

Motulsky, H., Christopoulos, A., 2004. Fitting models to biological data using linear and nonlinear regression: a practical guide to curve fitting. Oxford University Press, New York.

Pagter, M., Bragato, C., Brix, H., 2005. Tolerance and physiological responses of Phragmites australis to water deficit. Aquat. Bot. 81(4), 285-299.

Ranieri, E., 2003. Hydraulics of sub-superficial flow constructed wetlands in semi arid climate conditions. Water Sci. Technol. 47(7-8), 49-55. 
Reddy, M.J., Kumar, D.N., 2007. Multi-objective particle swarm optimization for generating optimal trade-offs in reservoir operation. Hydrol. Process. 21(21), 2897-2909.

Rost, S., Gerten, D., Bondeau, A., Lucht, W., Rohwer, J., Schaphoff, S., 2008. Agricultural green and blue water consumption and its influence on the global water system. Water Resour. Res. 44(9), W09405.

SEPAC (State Environmental Protection Administration of China), 2002. Environmental Quality Standard for Surface Water, China (GB3838-2002). China Environmental Science Press, Beijing. (in Chinese)

Sha, J., Liu, M., Wang, D., Swaney, D.P., Wang, Y., 2013. Application of the ReNuMa model in the Sha He river watershed: Tools for watershed environmental management. J. Environ. Manage. 124, 40-50.

Shantz, A.A., Burkepile, D.E., 2014. Context-dependent effects of nutrient loading on the coral-algal mutualism. Ecology 95(7), 1995-2005.

Sollie, S., Verhoeven, J.T., 2008. Nutrient cycling and retention along a littoral gradient in a Dutch shallow lake in relation to water level regime. Water Air Soil Poll. 193(1), 107-121.

Soltani, F., Kerachian, R., Shirangi, E., 2010. Developing operating rules for reservoirs considering the water quality issues: Application of ANFIS-based surrogate models. Expert Syst. Appl. 37(9), 6639-6645.

Song, K., Lee, S.H., Mitsch, W.J., Kang, H., 2010. Different responses of denitrification rates and denitrifying bacterial communities to hydrologic pulsing 
in created wetlands. Soil Biol. Biochem. 42(10), 1721-1727.

Teegavarapu, R.S., Ferreira, A.R., Simonovic, S.P., 2013. Fuzzy multiobjective models for optimal operation of a hydropower system. Water Resour. Res. 49(6), 3180-3193.

Wetzel, R.G., 2001. Limnology, 3rd ed. Academic Press, San Diego.

Xu, Z.H., Yin, X.A., Yang, Z.F., 2014. An optimisation approach for shallow lake restoration through macrophyte management. Hydrol. Earth Syst. Sci. 18(6), 2167-2176.

Yang, W., Yang, Z., Qin, Y., 2011. An optimization approach for sustainable release of e-flows for lake restoration and preservation: model development and a case study of Baiyangdian Lake, China. Ecol. Model. 222(14), 2448-2455.

Yang, Z.F., Zhao, Y., Xia, X.H., 2012. Nitrous oxide emissions from Phragmites australis-dominated zones in a shallow lake. Environ. Pollut. 166, 116-124.

Yin, X.A., Yang, Z.F., 2013. A reservoir operating model for directing water supply to humans, wetlands, and cones of depression. Ecol. Model. 252, 114-120.

Yoon, T., Rhodes, C., Shah, F.A., 2014. Upstream water resource management to address downstream pollution concerns: A policy framework with application to the Nakdong River basin in South Korea. Water Resour. Res. 51(2), 787-805.

Zhang, Y., Bleeker, A., Liu, J., 2015. Nutrient discharge from China's aquaculture industry and associated environmental impacts. Environ. Res. Lett. 10(4), 045002.

Zhao, Y., Xia, X.H., Yang, Z.F., 2013. Growth and nutrient accumulation of 
Phragmites australis in relation to water level variation and nutrient loadings in a shallow lake. J. Environ. Sci. 25(1), 16-25.

Zhao, Y., Yang, Z.F., Xia, X.H., Wang, F., 2012. A shallow lake remediation regime with Phragmites australis: Incorporating nutrient removal and water evapotranspiration. Water Res. 46(17), 5635-5644. 


\section{Figure captions:}

Fig. 1 Boundary and geographical location of Baiyangdian Wetland.

Fig. 2 Framework of the reservoir operation optimization model. (PU: plant uptake; BD: biological denitrification; CSP: continually submerged zone with plants; CSNP: continually submerged zone without plants; ISP: intermittently submerged zone with plants; ISNP: intermittently submerged zone without plants.)

Fig. 3 An optimal operation scheme for upstream reservoirs to improve nutrient assimilative capacity in Baiyangdian Wetland.

Fig. 4 Monthly nutrient assimilative and removal capacities in Baiyangdian Wetland under an optimal operation scheme for upstream reservoirs.

Fig. 5 Comparison of nutrient assimilative capacities in Baiyangdian Wetland under the optimal and assumptive scenarios for upstream reservoir operation.

Fig. 6 The dose-response relationship between annual total upstream water release and nutrient assimilative capacity in Baiyangdian Wetland. 
Figure 1

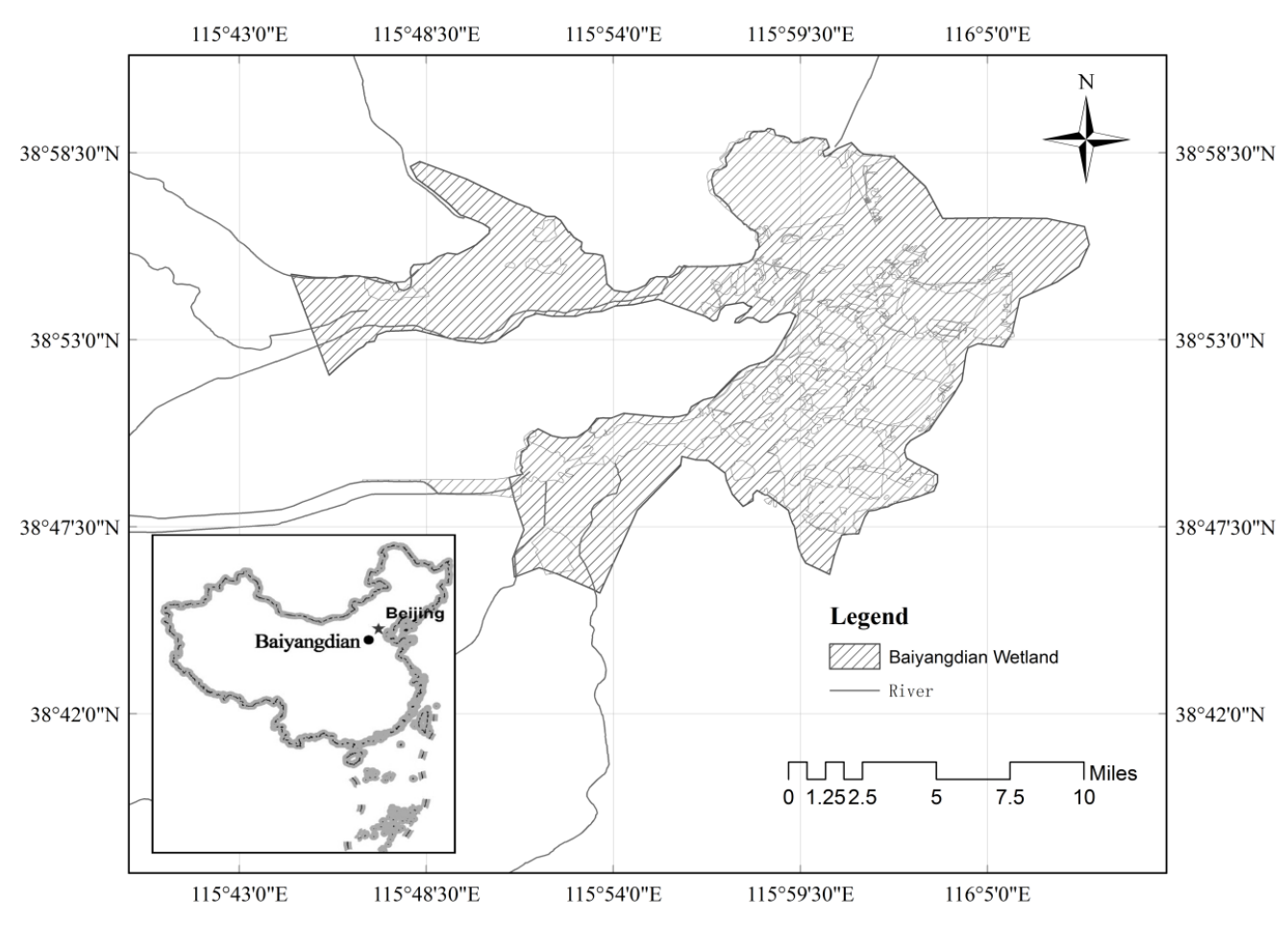




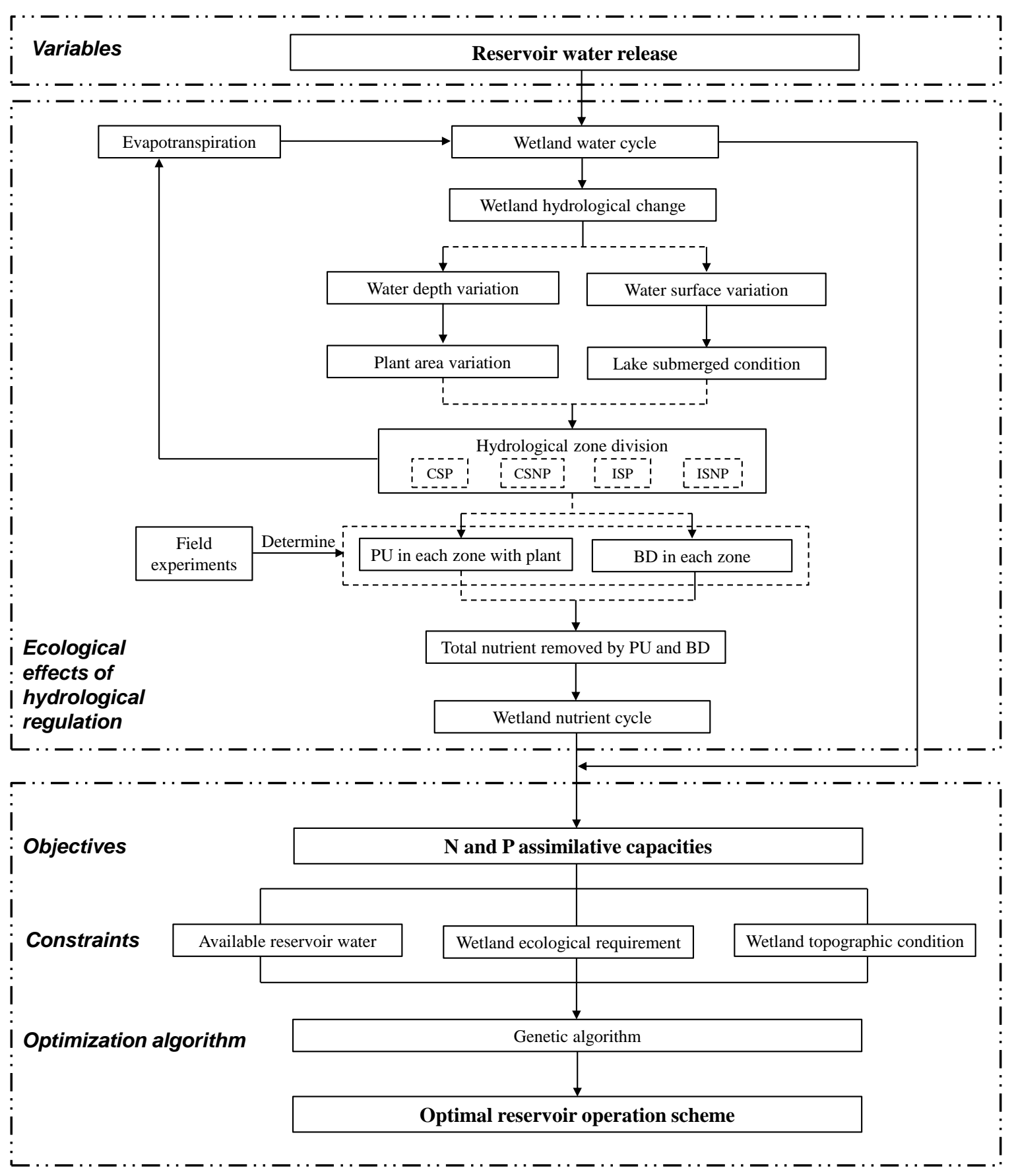


Figure 3

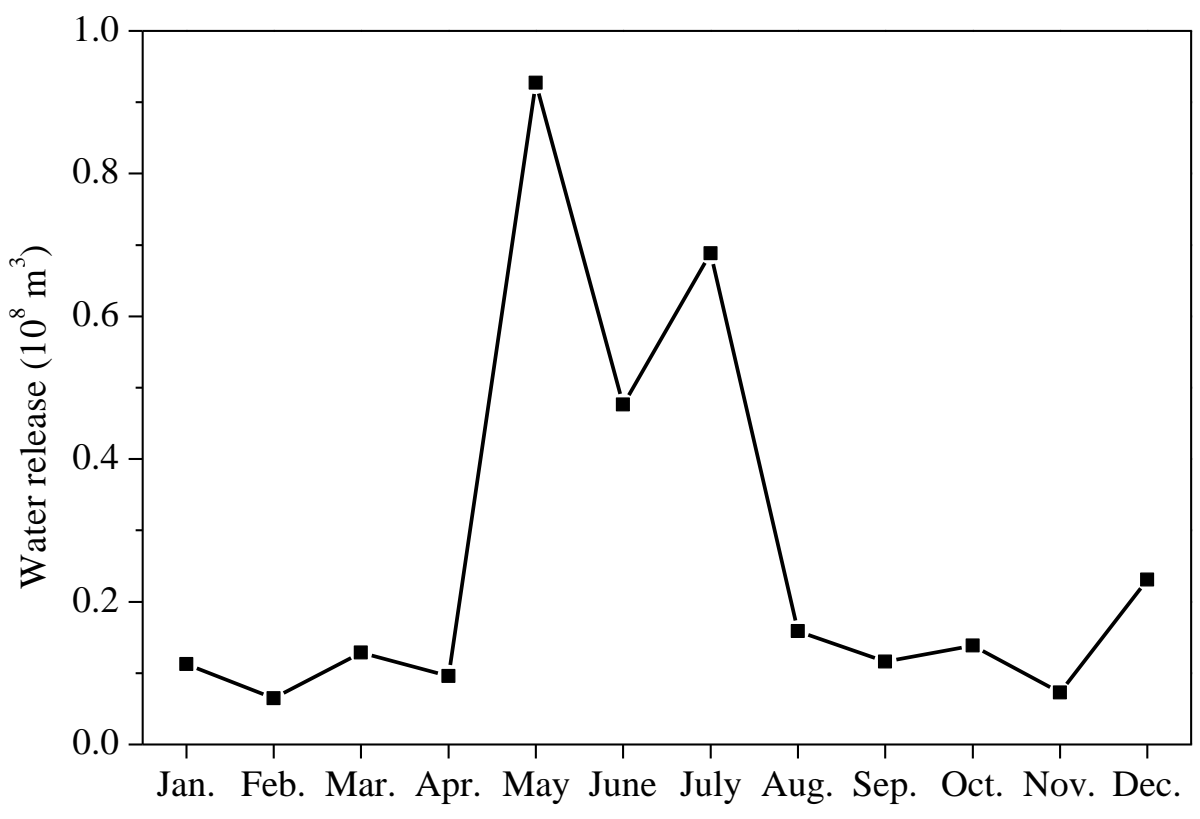


Figure 4
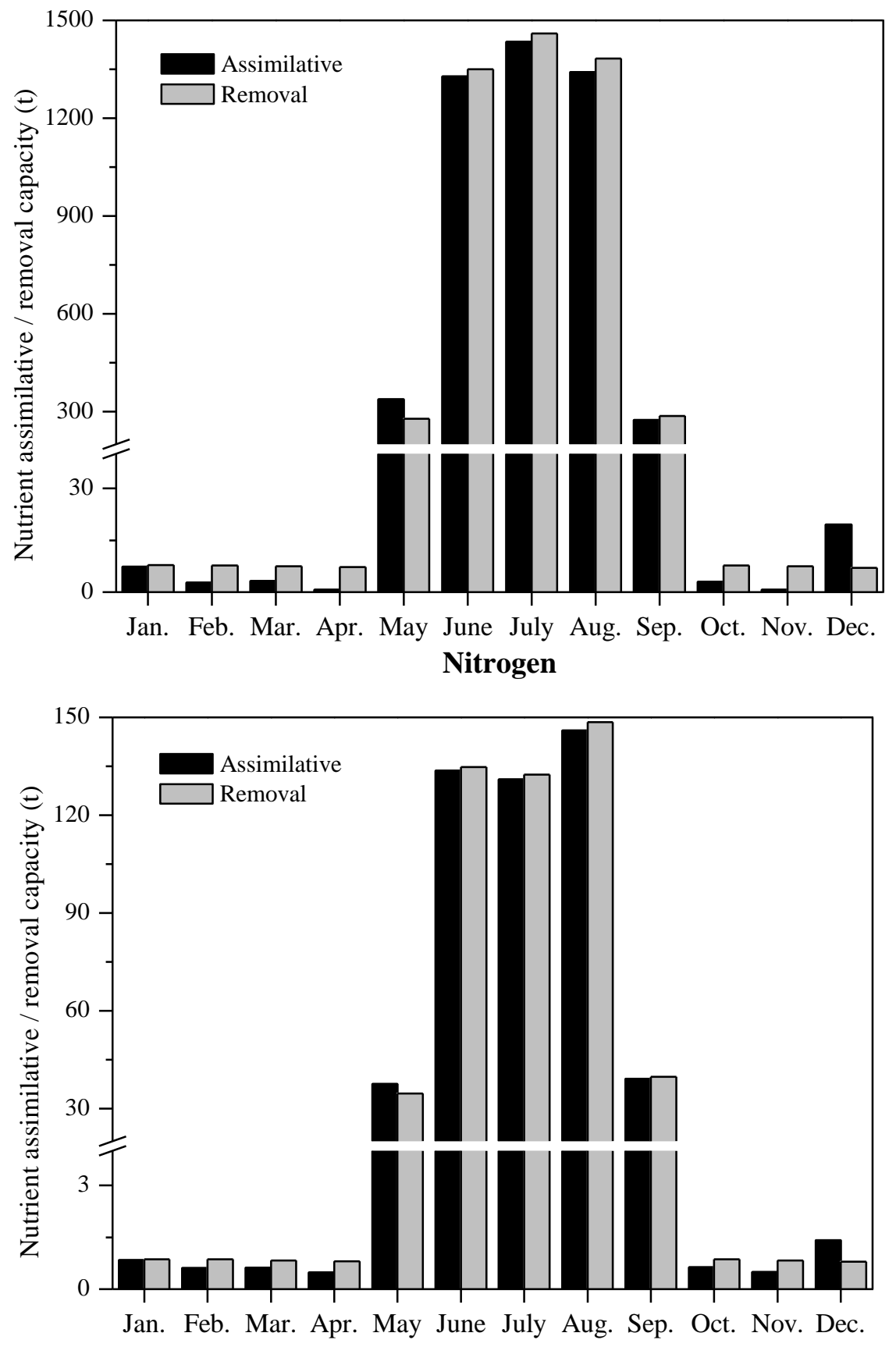

Phosphorus 
Figure 5
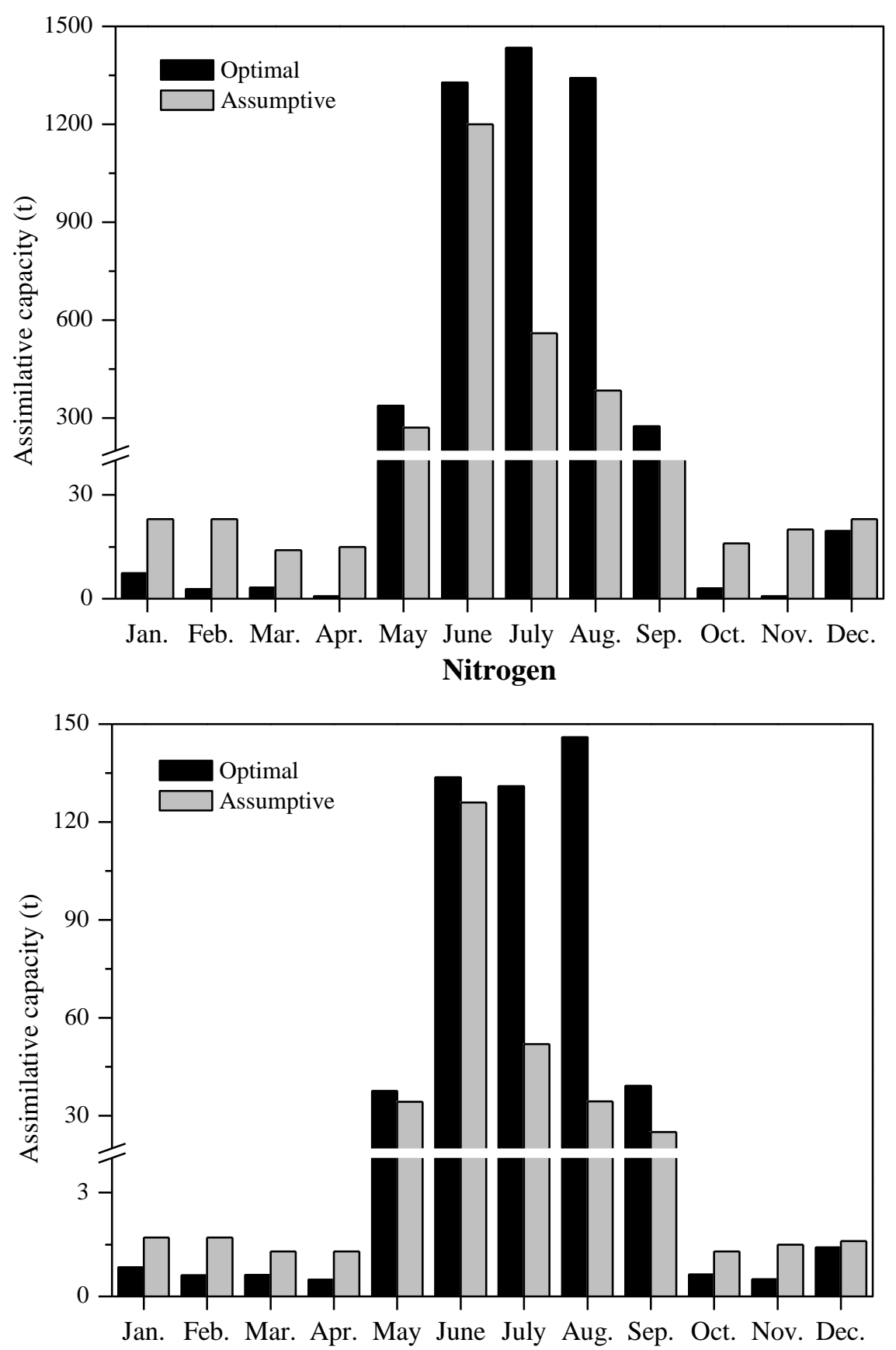

Phosphorus 
Figure 6

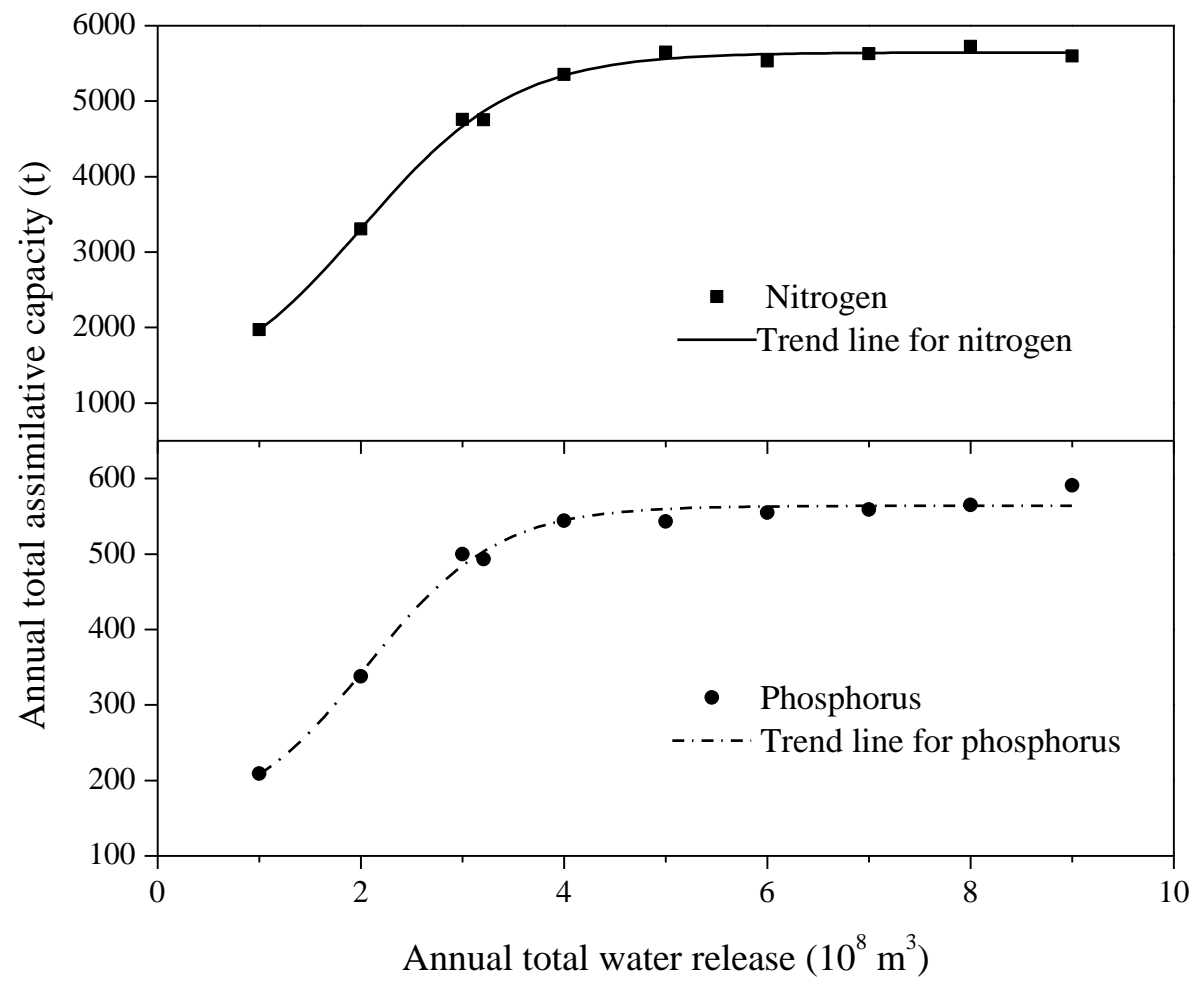


Table 1. Biomass and nutrient storage in reed tissues during the growing season in different hydrological zones of Baiyangdian Wetland

\begin{tabular}{ccccccc}
\hline \multirow{2}{*}{ Month } & \multicolumn{2}{c}{ Intermittently submerged zone $\left(\mathrm{g} \mathrm{m}^{-2}\right)$} & \multicolumn{4}{c}{ Continually submerged zone $\left(\mathrm{g} \mathrm{m}^{-2}\right)$} \\
\cline { 2 - 6 } & Biomass & N storage & P storage & Biomass & N storage & P storage \\
\hline May & 136.7 & 5.4 & 0.7 & 102.2 & 4.7 & 0.5 \\
June & 858.7 & 26.5 & 3.1 & 550.3 & 24.9 & 3.0 \\
July & 1537.5 & 60.6 & 7.0 & 930.7 & 43.6 & 4.8 \\
Aug. & 2038.9 & 77.1 & 9.3 & 1542.0 & 67.9 & 7.5 \\
Sept. & 2647.1 & 90.1 & 10.4 & 1823.2 & 74.2 & 8.5 \\
\hline
\end{tabular}

Table 2. The parameters and goodness-of-fit of the EC50 model applied in the relationship between upstream water release and nutrient assimilative capacity in Baiyangdian Wetland

\begin{tabular}{lcccccc}
\hline & \multicolumn{3}{c}{ Parameter values } & & Goodness of fit \\
\cline { 2 - 4 } & $A_{1}$ & $A_{2}$ & $a$ & $b$ & & Adjusted $R^{2}$ \\
\hline Nitrogen & 1030.89 & 5645.34 & 2.02 & 0.58 & \\
Phosphorus & 140.58 & 563.93 & 2.06 & 0.68 & \\
\hline
\end{tabular}

